\title{
Diets Rich in Natural Fibre Improve Carbohydrate Tolerance in Maturity-onset, Non-insulin Dependent Diabetics
}

\author{
Ruth M. Kay, W. Grobin, and N. S. Track \\ Departments of Surgery, Nutrition and Clinical Biochemistry, University of Toronto and Toronto Western Hospital, \\ Mount Sinai Hospital and Baycrest Geriatric Centre, Toronto, Ontario, Canada
}

Summary. The influence of low and high fibre diets upon carbohydrate tolerance was examined in five maturity-onset, non-insulin dependent diabetics. After 14 days on a diet rich in natural fibre $(30 \mathrm{~g} /$ day), the subjects consumed a high fibre (13 g) test meal. They, then ate a low fibre diet $(10 \mathrm{~g} /$ day $)$ followed by a low fibre $(1 \mathrm{~g})$ test meal. Mean basal plasma glucose concentrations were similar after both fibre diets; however, both mean basal plasma insulin and gastric inhibitory polypeptide (GIP) were significantly lower after the high fibre diet. After the high fibre test meal, significantly lower mean plasma glucose, insulin and GIP concentrations were measured. This study is the first study to demonstrate the ability of an institutionally supervised diet of natural foodstuffs rich in fibre to improve carbohydrate tolerance in maturity-onset, non-insulin dependent diabetics. This finding is relevant to the dietary management of diabetics.

Key words: Carbohydrate tolerance, dietary fibre, diabetes mellitus, plasma glucose, insulin, gastric inhibitory polypeptide.

Since fibre causes an improvement of carbohydrate tolerance in human subjects, it is an important factor to be considered in the dietary management of noninsulin dependent diabetics. The introduction of fibre into the diabetic diet has been approached in two ways in closely supervised studies: the first is the addition of fibre to meals [1] while the second is an overall enrichment of the diet with fibre-rich foods $[2,3]$. Both of these approaches have demonstrated the beneficial effects of dietary fibre upon carbohydrate tolerance in diabetics. However, if fibre-rich diets are going to be useful to a large diabetic population, then it is necessary for institutional nutrition staff and kitchen to be able to prepare and supervise the diabetics' fibre-rich dietary regimen.

This study has taken this latter practical approach to assess the effect of fibre present in foods commonly eaten by Western populations upon carbohydrate tolerance in five maturity-onset, non-insulin dependent diabetics confined to a geriatric care centre.

\section{Subjects and Methods}

Five maturity-onset, non-insulin dependent diabetics ( 4 females, 1 male) were studied (Table 1). They were all residents of a medically supervised nursing home and were habitually consuming a normal Western diet ( $15 \mathrm{~g} /$ day dietary fibre). The study was approved by the Human Experimentation Committee of the University of Toronto and informed consent was obtained.

Patients consumed a high fibre (HF) diet (approximately $30 \mathrm{~g} / \mathrm{d}$ dietary fibre) for 14 days, followed by a similar period on a low fibre (LF) diet (approximately $10 \mathrm{~g} / \mathrm{d}$ dietary fibre). A daily diet plan is outlined in Table 2. All food was prepared in a central kitchen and the menu rotated during the course of the study. On the last day of each of the high and low fibre diet periods, subjects consumed a weighed breakfast at $0800 \mathrm{~h}$. No other food or beverage was permitted until $1230 \mathrm{~h}$ when a basal blood sample was obtained and subjects consumed a weighed meal consisting of normal foods which contained either $1 \mathrm{~g}$ (LF) or $13 \mathrm{~g}$ (HF) of indigenous dietary fibre. The test meals were identical in other nutrients (Table 3) and are outlined in Table 4. All foods were consumed under investigators' supervision. Diet composition was calculated from recently published tables which provide data on total soluble and non-soluble dietary fibre in food $[4,5]$. Treatment with oral hypoglycaemic agents and other medications was kept constant throughout the study.

Blood samples were collected via an indwelling venous catheter. After the basal sample at $1230 \mathrm{~h}$, five postprandial samples were taken at $30 \mathrm{~min}$ intervals. Blood was transferred to heparinised tubes, centrifuged immediately and the resulting plasma was stored at $-20^{\circ} \mathrm{C}$.

Plasma glucose was determined by the glucose oxidase method (Beckman glucose analyzer 2); plasma immunoreactive insulin 
Table 1. Medical background to test subjects

\begin{tabular}{|c|c|c|c|c|c|c|}
\hline Sex & $\begin{array}{l}\text { Age } \\
\text { (yrs.) }\end{array}$ & $\begin{array}{l}\% \text { Ideal } \\
\text { weight }^{\mathrm{a}}\end{array}$ & $\begin{array}{l}\text { Duration } \\
\text { diabetes }\end{array}$ & $\begin{array}{l}\text { Diabetic } \\
\text { therapy }\end{array}$ & $\begin{array}{l}\text { Other } \\
\text { medication }\end{array}$ & $\begin{array}{l}\text { Other } \\
\text { illnesses }\end{array}$ \\
\hline$F$ & 88 & 122 & 5 years & Diet & Ferrous sulphate & \\
\hline$F$ & 72 & 151 & 10 years & Diet & $\begin{array}{l}\text { Furosemide, } \\
\text { anturan, } \\
\text { Dilantin, } \\
\text { aldactone, } \\
\text { phenobarbital }\end{array}$ & $\begin{array}{l}\text { Immobile due to } \\
\text { CVA, atrial } \\
\text { fibrillation }\end{array}$ \\
\hline M & 87 & 84 & 14 years & Diet & Diazyde, lanoxin & COPD, ASHD \\
\hline$F$ & 72 & 101 & 8 years & $\begin{array}{l}\text { Metformin, } \\
\text { glibenclamide }\end{array}$ & Thioridiazine, ASA & CVA, hemiplegia \\
\hline$F$ & 88 & 106 & 42 years & $\begin{array}{l}\text { Diet, } \\
\text { tolbutamide }\end{array}$ & $\begin{array}{l}\text { Acetaminophen, } \\
\text { digoxin }\end{array}$ & Osteoarthritis \\
\hline
\end{tabular}

a Calculated according to Dequeker et al. [17]

Table 2. Sample daily menu plan during low and high fibre diet periods

\begin{tabular}{|c|c|c|}
\hline & Low fibre & High fibre \\
\hline Breakfast & $\begin{array}{l}\text { orange juice, } \\
\text { cream of wheat, white } \\
\text { toast, butter, milk, } \\
\text { coffee }\end{array}$ & $\begin{array}{l}\text { orange and banana slices, } \\
\text { oat porridge with bran, } \\
\text { wholemeal toast, } \\
\text { butter, } \\
\text { milk, coffee }\end{array}$ \\
\hline Lunch & $\begin{array}{l}\text { consomme, } \\
\text { roast chicken, } \\
\text { boiled potato, } \\
\text { tomato slices, } \\
\text { canned grapefruit sec- } \\
\text { tions, } \\
\text { tea with lemon }\end{array}$ & $\begin{array}{l}\text { large raw salad, } \\
\text { roast chicken, } \\
\text { baked potato,, } \\
\text { green beans, } \\
\text { broccoli; } \\
\text { fresh apple and pear } \\
\text { slices, } \\
\text { tea with lemon }\end{array}$ \\
\hline Dinner & $\begin{array}{l}\text { cream of tomato soup, } \\
\text { poached salmon, } \\
\text { mashed potato, } \\
\text { boiled courgettes, } \\
\text { white roll, } \\
\text { custard pudding, } \\
\text { coffee, milk }\end{array}$ & $\begin{array}{l}\text { pea soup, } \\
\text { poached salmon, } \\
\text { sweet corn, } \\
\text { peas, } \\
\text { salad, } \\
\text { wholemeal bread, } \\
\text { melon, } \\
\text { coffee, milk }\end{array}$ \\
\hline
\end{tabular}

(IRI) [6] and gastric inhibitory polypeptide (GIP) [7] were measured by double antibody radioimmunoassays. Wright's guinea pig anti-insulin serum (lot 623), human insulin standards (Novo Industri, Copenhagen, DK) and mono-iodinated bovine insulin were used in the insulin radioimmunoassay: the lower detection limit was $30 \mathrm{ng} / 1$. Brown's guinea pig anti-GIP serum (GP 25), porcine GIP standards and mono-iodinated GIP were used in the GIP radioimmunoassay; the lower detection limit was $60 \mathrm{ng} / \mathrm{l}$. The within and between assay reproducibility expressed as coefficient of variation was 0.08 and 0.14 at a level of $250 \mathrm{ng} / 1$.

The data were analysed using Student's t test for paired comparisons.

\section{Results}

All subjects tolerated both diets without difficulty and no significant changes in body weight occurred during either phase of the study. All subjects noted an increase in bowel frequency and stool bulk during high fibre diet. Medication did not differ between test periods. The LF and HF test meals were consumed over 15 and 25 min periods.

Basal plasma glucose concentrations were similar after the LF and HF diet periods (Fig. 1). After the LF meal, plasma glucose peaked $60-90$ min postprandially and returned toward baseline by $150 \mathrm{~min}$. The maximum plasma glucose increase was $30 \%$. By contrast, after the HF meal, the maximum plasma glucose increase was $14 \%$ with significantly lower concentrations detected 30,60 and 90 min postprandially.

Lower basal plasma IRI concentrations were measured after the HF diet period (Fig. 1). Sixty min after the start of the LF test meal, plasma IRI increased significantly $(\mathrm{p}<0.05)$ and declined gradually over the remaining $90 \mathrm{~min}$ of the test. After the HF test meal, significantly lower plasma IRI was detected at 60,90 and $120 \mathrm{~min}$. The increment in the plasma IRI response was significantly reduced $60 \mathrm{~min}$ after the HF meal $(7.7 \pm 4.3 \mathrm{mU} / \mathrm{l}$ (HF) vs $14.8 \pm 9.8 \mathrm{mU} / \mathrm{l} ; \mathrm{p}<0.05)$.

Lower basal plasma GIP concentrations were detected after the HF diet period (Table 5). After the LF meal, plasma GIP concentrations rose in parallel with IRI and remained elevated over the $150 \mathrm{~min}$ sampling period. Plasma GIP concentrations at 30 and $60 \mathrm{~min}$ postprandially were lower $(\mathrm{p}<0.05)$ after the HF test meal. GIP increment responses did not differ after the two test meals. 
Table 3. Nutrient composition of low and high fibre test meals for the five non-insulin dependent aged diabetic subjects

\begin{tabular}{lcr}
\hline & Low fibre & High fibre \\
\hline Energy Kcal & $343 \pm 21$ & $343 \pm 47$ \\
Protein g & $20.5 \pm 2.7$ & $19.1 \pm 2.2$ \\
Fat g & $14.8 \pm 0.3$ & $14.5 \pm 0.3$ \\
Sugars $^{\mathrm{a}} \mathrm{g}$ & $27.1 \pm 1.6$ & $27.4 \pm 1.7$ \\
Starch g $^{\text {Dietary fibre }}{ }^{\mathrm{b}} \mathrm{g}$ & $9.0 \pm 2.1$ & $9.0 \pm 2.0$ \\
\hline
\end{tabular}

a free monosaccharides and disaccharides [4]; proportions of glucose and fructose (free and disaccharide-derived) were similar in both diets [5]

${ }^{b}$ total soluble and non-soluble dietary fibre calculated from Paul and Southgate [4]
Table 4. Composition of low and high fibre test meals

\begin{tabular}{|c|c|c|c|}
\hline Low fibre & $\begin{array}{l}\text { Weight } \\
\text { (g) }\end{array}$ & High fibre & $\begin{array}{l}\text { Weight } \\
\text { (g) }\end{array}$ \\
\hline $\begin{array}{l}\text { White bread } \\
\text { Chicken breast } \\
\text { Mayonnaise } \\
\text { Potato } \\
\text { Tomato juice } \\
\text { Gelatin dessert }\end{array}$ & $\begin{array}{r}28 \\
63 \\
15 \\
20 \\
185 \\
149\end{array}$ & $\begin{array}{l}\text { Whole wheat bread } \\
\text { Chicken breast } \\
\text { Mayonnaise } \\
\text { Green beans } \\
\text { Peas } \\
\text { Salad (raw tomato, } \\
\text { carrot, celery, } \\
\text { green pepper, } \\
\text { radish) } \\
\text { Fresh fruit cup } \\
\text { (canteloupe, } \\
\text { banana, pear, apple, } \\
\text { grapes, orange } \\
\text { juice) }\end{array}$ & $\begin{array}{r}30 \\
63 \\
15 \\
100 \\
80\end{array}$ \\
\hline
\end{tabular}

Table 5. Mean ( \pm SEM) basal and postprandial plasma GIP responses to low and high fibre meals in five non-insulin dependent aged diabetics

\begin{tabular}{|c|c|c|c|c|c|c|}
\hline & \multirow[b]{2}{*}{ Basal } & \multicolumn{5}{|c|}{ Minutes postprandial } \\
\hline & & 30 & 60 & 90 & 120 & 150 \\
\hline \multicolumn{7}{|l|}{ GIP (ng/l) } \\
\hline Low fibre & $891 \pm 174$ & $1696 \pm 255$ & $1579 \pm 237$ & $1616 \pm 395$ & $1660 \pm 256$ & $1303 \pm 119$ \\
\hline High fibre & $581 \pm 1.19$ & $1283 \pm 173$ & $1076 \pm 170$ & $1194 \pm 244$ & $1415 \pm 164$ & $1248 \pm 171$ \\
\hline $\mathrm{p}$ & $<0.05$ & $<0.05$ & $<0.05$ & NS & NS & NS \\
\hline
\end{tabular}

\section{Discussion}

The study is the first to demonstrate that an institutionally supervised diet of natural foodstuffs rich in fibre significantly reduces the postprandial rise of plasma glucose and insulin in maturity-onset, noninsulin dependent diabetics. This observation is not novel, but the approach to achieve it is. Previous studies have utilised either meals supplemented with fibre [1] or fibre-enriched diets $[2,3]$. The fact that a comparable effect can be achieved in a geriatric care centre environment is particularily relevant to diet therapy for diabetics. The observed effect cannot be ascribed to alteration in carbohydrate intake $[8,9]$ since fibre content was the only variable in the diets and test meals.

A significant portion of the carbohydrate in the high fibre diet was present in the form of fresh fruit and vegetables. A diet based upon raw plant food has previously been reported to reduce insulin requirements in diabetics [10]; this effect was attributed in part to impaired digestibility of unruptured cells [11]. In the present sutdy, it is not know if the observed reduction in postprandial glycaemia was due to a quantitative reduction in carbohydrate absorption or
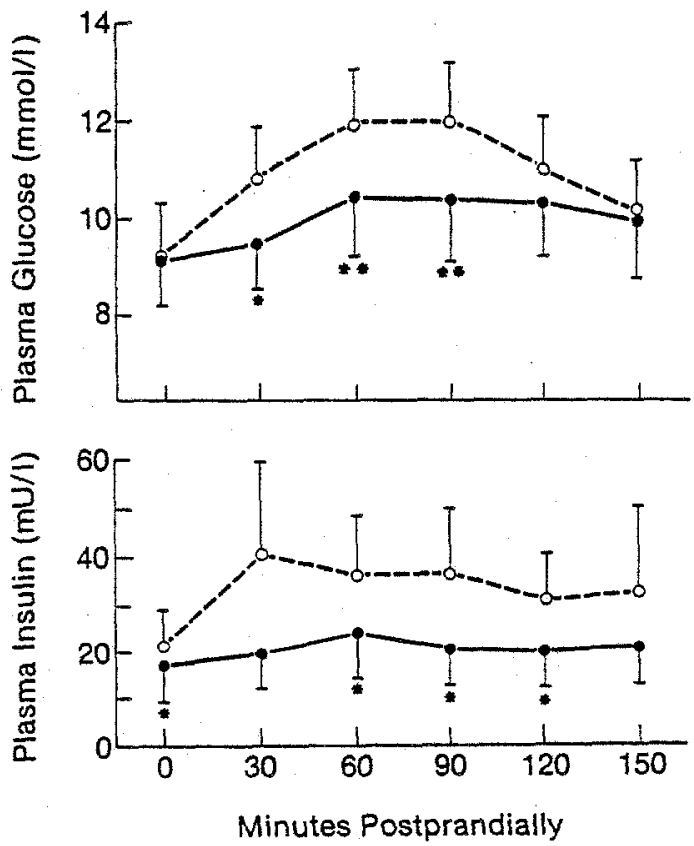

Fig. 1. Mean ( $\pm S E M)$ basal and postprandial plasma glucose and insulin responses to meals low $\left(\mathrm{O}_{-}-\mathrm{O}\right)$ or high (-) in fibre in five non-insulin dependent diabetics. Where the high fibre means are significantly below the low fibre, they are denoted by asterisks: ${ }^{*} \mathrm{p}<0.05,{ }^{* *} \mathrm{p}<0.01$ 
due to an alteration in the rate of absorption or peripheral glucose uptake.

The diminished plasma insulin increase after the high fibre meal paralleled the glycaemic response and is consistent with the effects observed after ingestion of other types of fibre including that present in normal foods and gel forming polysaccharides such as guar [12-15]. Lower basal plasma insulin and GIP concentrations perhaps reflect an overall lowering of glucoregulatory hormones in response to 14 days of the high fibre diet in these diabetics. Reduced postprandial GIP responses are consistent with previous observations [15]. Basal and postprandial plasma GIP concentrations may reflect an alteration in the turnover of intestinal GIP caused by a more distal jejunal site of glucose absorption.

The improved carbohydrate tolerance detected in this study was achieved with diets consisting of normal, palatable foodstuffs. The results demonstrate a significant reduction in both basal and postprandial insulin concentrations after the high fibre diet/meal. Significantly reducing the demand for pancreatic insulin could have important implications: a less challenged pancreas with a better insulin reserve may reduce the risk of both diabetes and its complications [16].

Acknowledgement. This study was supported in part by the Canadian Medical Research Council and the Harold Tanenbaum Department of Research, Mount Sinai Hospital.

\section{References}

1. Jenkins DJA, Wolever TMS, Nineham R, Taylor R, Metz GL, Bacon S, Hockaday TDR (1978) Guar crispbread in the diabetic diet. Br Med J II: 1744-1746

2. Kiehm TG, Anderson JW, Ward K (1976) Beneficial effect of a high carbohydrate diet on hyperglycemic diabetic men. Am J Clin Nutr 29: 895-899

3. Miranda PM, Horwitz DL (1978) High-fiber diets in the treatment of diabetes mellitus. Ann Intern Med 88: 482-486
4. Paul AS, Southgate DAT (1978) McCance and Widdowson's: The composition of foods. H.M.S.O., London

5. Hardinge MG, Swarner JB, Crooks H (1965) Carbohydrate in foods. J Am Diet Assoc 46: 197-204

6. Soeldner JS, Slone C (1965) Critical variables in radioimmunoassay of serum insulin using the double antibody technic. Diabetes 14: 771-779

7. Kuzio M, Dryburgh JR, Malloy KM, Brown JC (1974) Radioimmunoassay for gastric inhibitory polypeptide. Gastoenterology $66: 357-364$

8. Brunzell JD, Lemer RL, Porte D, Bierman EL (1971) Improved glucose tolerance with high carbohydrate feeding in mild diabetes. N Engl J Med 284: 521-524

9. Simpson RW, Mann JI, Eaton J, Carter RD, Hockaday TDR (1979) High-carbohydrate diets and insulin-dependent diabetes. Br Med J II: 523-525

10. Douglass MI (1975) Raw diet and insulin requirements. Ann Intern Med 82: 61-62

11. Horwitz DL, Slowie $L$ (1975) Raw diet in diabetes mellitus. Ann Intern Med 82: 853-854

12. Jenkins DJA, Leeds AR, Gassull MA, Cochet B, Alberti KGMM (1977) Decrease in postprandial insulin and glucose concentrations by guar and pectin. Ann Intern Med 86: 20-23

13. Goulder TJ, Alberti KGMM (1978) Dietary fibre and diabetes. Diabetologia 15: 285-287

14. Albrink MJ, Newman T, Davidson PC (1979) Effect of highand low-fiber diets on plasma lipids and insulin. Am J Clin Nutr 32: 1486-1491

15. Morgan LM, Goulder TJ, Solakis DT, Marks V, Aiberti KGMM (1979) Effect of unabsorbable carbohydrate on gut hormones. Diabetologia 17: 85-89

16. Turkington RW, Weindling HK (1978) Insulin secretion in the diagnosis of adult-onset diabetes mellitus. JAMA 240: 833-836

17. Dequeker JV, Baeyens JP, Classens J (1969) The significance of stature as a clinical measurement of aging. J Am Geriatr Soc 17: $169-179$

Received: April 9, 1980;

and in revised form: September 16, 1980

Dr. Ruth M. Kay

Lab. 1223

Toronto Western Hospital

399 Bathurst Street

Toronto, Ontario M5T 2S8

Canada 